\title{
Aircraft Measurements of Physicochemical Evolution of Atmospheric Aerosols in Air Pollution Plumes over a Megacity and Suburban Areas
}

\author{
Taehyun Park', Yongjoo Choi ${ }^{1 \dagger}$, Jinsoo Choi ${ }^{2}$, Junyoung Ahn ${ }^{3}$, Jinsoo Park ${ }^{2}$, Yonghwan Lee', \\ Jihee Ban ${ }^{1}$, Gyutae Park ${ }^{1}$, Seokwon Kang ${ }^{1}$, Kyunghoon Kim ${ }^{1}$, Beom-Keun Seo ${ }^{4}$, Jongho Kim ${ }^{4}$, \\ Soobog Park ${ }^{5}$, Hyunjae Kim², HaEun Jeon², Taehyoung Lee ${ }^{1^{*}}$ \\ ${ }^{1}$ Department of Environmental Science, Hankuk University of Foreign Studies, Gyeonggi 17035, Korea \\ ${ }^{2}$ Climate and Air Quality Research Department, National Institute of Environmental Research, Incheon 22689, Korea \\ ${ }^{3}$ Air Quality Forecasting Center, National Institute of Environmental Research, Incheon 22689, Korea \\ ${ }^{4}$ Department of Environmental Engineering, Hanseo University, Chungcheognam 31962, Korea \\ ${ }^{5}$ Department of Flight Operations, Hanseo University, Chungcheognam 31962, Korea
}

\begin{abstract}
As part of the Megacity Air Pollution Studies (MAPS)-Seoul campaign, three types of research flights were conducted over the Seoul Metropolitan Area (SMA) from May till June 2015 to measure the spatial distribution of a pollution plume near a power plant and petrochemical complex, the vertical profiles of pollutants on the western coast of Korea, and the pollutant distribution in the SMA. The pollution plume $(\sim 0-700 \mathrm{~m})$ was highly concentrated and dominated by organic aerosol (OA), which very likely oxidized in the plume, as it showed slightly less oxidation near the source and significantly less oxidation at altitudes above the plume. One vertical profile displayed transitions in concentration and changes in the dominant components, suggesting that the particle sources and/or processing differed above $\sim 1000 \mathrm{~m}$; below $1000 \mathrm{~m}$, where the total mass and OA concentrations were high, sulfate and likely transport sources predominated. The other profile, which was assessed during a separate flight, exhibited sharp increases in the OA number concentration and mean diameter, less oxidized organic content, and higher organic and nitrate concentrations above $1400 \mathrm{~m}$, indicating high-altitude transport and a cleaner boundary layer. Finally, flights investigating the distributions of pollutants in the central, upwind, and downwind SMA regions generally detected high levels of oxidation downwind as well as different aerosol masses between the low and high altitudes. This study highlights the necessity of understanding the complex vertical structures of particle layers, such as those identified in and around the SMA, in order to facilitate the adoption of efficient air quality control strategies and enhance air quality forecasting.
\end{abstract}

Keywords: Air pollution plume; Aircraft observations; Aerosol aging; Photochemical processing; Spatial distribution.

\section{INTRODUCTION}

Seoul is one of the largest metropolitan areas in the world, and half of the Korean population lives in the Seoul Metropolitan Area (SMA), which constitutes only $12 \%$ of the country's area (Statistics Korea, 2016). The population of the SMA continues to increase due to urbanization. Air

\footnotetext{
${ }^{\dagger}$ Now at Research Institute for Global Change, Japan Agency for Marine-Earth Science and Technology (JAMSTEC), Yokohama, Japan.

* Corresponding author.

Tel.: 82-31-330-4039; Fax: 82-31-330-4529

E-mail address: thlee@hufs.ac.kr
}

pollution characterization in the SMA is complex due to the high population density and a wide variety of air pollution sources, including transportation, industry, and residential activities such as meat cooking. In addition, a large amount of energy consumption in various forms (e.g., fossil fuel combustion, biomass burning) contributes to the high levels of air pollution in megacities (Gurjar et al., 2016).

Numerous studies have been conducted to understand the characteristics of domestic emissions and the influence of pollutants transported long-range from China (Lee et al., 2012; Park et al., 2013; Boris et al., 2015; Lee et al., 2015; Bae et al., 2017; Lee et al., 2019). Choi et al. (2016) identified the sources of organic aerosol (OA) in $\mathrm{PM}_{10}$ (particulate matter with a diameter of $<10 \mu \mathrm{m}$ ) in Seoul, Korea, in 2010 2011, indicating that most OA was emitted from anthropogenic sources such as combustion of fossil fuel and biomass burning. Oh et al. (2015) analyzed high-PM 10 episodes (daily 
mean $\mathrm{PM}_{10}>100 \mu \mathrm{g} \mathrm{m}^{-3}$ ) in Seoul, finding that such events were often caused by long-range pollutant transport from China with prevailing westerly winds. Although sources and select seasons have been investigated in Seoul itself, regional-scale air quality and chemistry, which affect both the metropolitan area and broad areas downwind through atmospheric diffusion and transport, remain unexplored (Cassiani et al., 2013).

In addition, ground-based measurements, especially those at fixed locations, are limited in their ability to elucidate air pollution behavior throughout the vertical and spatial distributions of the plume. As a result, numerous studies using aircraft measurements have endeavored to understand air pollution behavior and characteristics, varied aerosol features and types including aerosol spatial distributions, biomass burning smoke, emissions from volcanic eruptions, and dust storms (Hunton et al., 2005; DeCarlo et al., 2008; Wang et al., 2008; Belchschmidt et al., 2012; Zamora et al., 2016). DeCarlo et al. (2008) conducted the first aircraft study on the regional evolution of aerosol chemistry in a tropical megacity, using a High-Resolution Time-of-Flight Aerosol Mass Spectrometer (HR-ToF-AMS) to measure the spatial non-refractory (NR)-PM $\mathrm{PM}_{1}$ (particles with an aerodynamic diameter of $<1 \mu \mathrm{m}$ ) species (OA, sulfate, nitrate, and chloride) and other air pollutant species on board the NSF/NCAR C-130 aircraft, as part of the Megacity Initiative: Local and Global Research Observations (MILAGRO) field campaign. Hecobian et al. (2011) investigated chemical characteristics of 495 biomass burning plumes inboard the NASA DC-8. The Aerosol Characterization Experiment-Asia (ACE-Asia) included AMS measurements (at a lower mass resolution, using an earlier version of the instrument) over Japan and the Western Pacific (Bahreini et al., 2003); however, the measurements were too limited in duration and spatial coverage to provide a broad overview of the vertical and horizontal chemical trends in the area, and were in any case somewhat removed from the SMA. A deeper understanding of the physicochemical processes in the SMA will facilitate the adoption of more efficient air quality control strategies and enhance air quality forecasting.

In this study, we characterized aerosol number distributions as a function of size and mass concentrations of sulfate, nitrate, ammonium, and organics in polluted air plumes, and investigated the horizontal and vertical distributions of each species in the atmosphere using an ultra-high-sensitivity aerosol spectrometer (UHSAS) and HR-ToF-AMS on board the Hanseo King Air C90GT aircraft, as a part of the Megacity Air Pollution Studies-Seoul (MAPS-Seoul) campaign. These aircraft-based NR-PM 1 observations were the first of their kind in Korea, and this research flight constitutes a preliminary study in preparation for the Korea-United States Air Quality (KORUS-AQ) campaign (Kim et al., 2018). The organic-matter-to-organic-carbon ratio (OM:OC), oxygen-tocarbon ratio $(\mathrm{O}: \mathrm{C})$, and hydrogen-to-carbon ratio $(\mathrm{H}: \mathrm{C})$ from the HR-ToF-AMS, the vertical and horizontal distributions for which have also not been previously characterized over Korea, are used to explain and characterize the oxidation state of OA (Aiken et al., 2008, Canagaratna et al., 2015).

\section{METHODS}

\section{Measurement Site}

Seven research flights (RFs) were conducted over the SMA from May to June 2015, based on a Hanseo King Air C90GT aircraft (Textron Aviation Inc.) (Fig. S1) during the MAPS-Seoul campaign (Fig. 1). These research flights used an HR-ToF-AMS (Aerodyne Inc., USA) and a UHSAS (Droplet Measurement Technologies Inc., USA) to record measurements. Table 1 presents brief descriptions of these flights. They can be categorized into three sets of research flights exploring a specific focus: (1) the spatial distribution of the pollution plume (RF02), (2) vertical spiral flights on the coasts of Taean and Anmyeon, in the western part of Korea (RF03 and RF06), and (3) areas around the SMA (RF01, RF04, RF05, and RF07). The details concerning flight information and weather conditions are described in Kim et al. (2018).

\section{Instrumentation}

The operation of the HR-ToF-AMS has been described in detail elsewhere (Jayne et al., 2000; Jimenez et al., 2003;
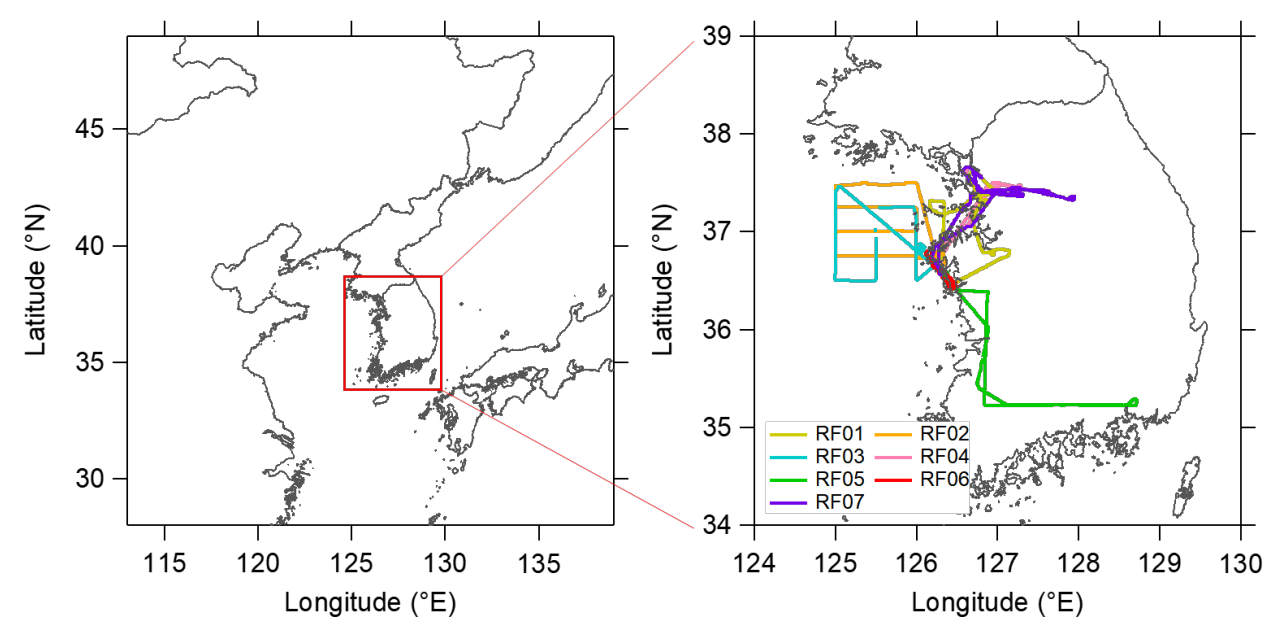

Fig. 1. Maps of East Asia. The red square outlines the South Korean peninsula. The right-hand panel depicts the flight tracks of the research flights (RFs) aboard the King Air aircraft. 
Table 1. Brief descriptions of the research flights during the MAPS-Seoul campaign.

\begin{tabular}{|c|c|c|c|c|c|}
\hline \multirow{2}{*}{$\begin{array}{l}\text { Research } \\
\text { flight \# }\end{array}$} & \multirow{2}{*}{ Date } & \multirow{2}{*}{ Time } & \multicolumn{2}{|c|}{ Altitude (m) } & \multirow{2}{*}{ Flight path } \\
\hline & & & Mean & $\operatorname{Max}$ & \\
\hline RF 01 & May 27 & $12: 30-15: 30$ & 641 & 1133 & Around Seoul Metropolitan Area \\
\hline RF 02 & June 2 & $16: 00-18: 00$ & 774 & 1590 & The coast of west part of Korea \\
\hline RF 03 & June 6 & $14: 00-17: 00$ & 1101 & 1900 & The coast of Taean, Korea (spiral flight) \\
\hline RF 04 & June 7 & $09: 30-12: 30$ & 796 & 2020 & Taean-Seoul-Wonju-Taean \\
\hline RF 05 & June 7 & $13: 30-16: 30$ & 1226 & 1906 & Taean-Gwangju-Busan-Gwangju-Taean \\
\hline RF 06 & June 13 & $09: 30-11: 30$ & 1143 & 2722 & Anmyeon, west part of Korea (spiral flight) \\
\hline RF 07 & June 13 & $13: 30-17: 00$ & 988 & 2246 & Taean-Gimpo-Seoul-Wonju-SMA-Taean \\
\hline
\end{tabular}

Drewnick et al., 2005; DeCarlo et al., 2006; Canagaratna et al., 2007; Lee et al., 2015). In brief, ambient air was pulled through a URG cyclone at a flow rate of $3 \mathrm{~L} \mathrm{~min}^{-1}$ to remove particles with an aerodynamic diameter $>2.5 \mu \mathrm{m}$, before HR-ToF-AMS analysis. The ambient air entered the HRToF-AMS through a $110 \mu \mathrm{m}$ diameter critical orifice, passing into the interior vacuum; the average flow rate through the inlet was $0.105 \mathrm{~L} \mathrm{~min}^{-1}$. The AMS uses an aerodynamic lens to focus $\sim 35 \mathrm{~nm}$ to $\sim 1 \mu \mathrm{m}$ ambient particles into a narrow particle beam, which then travels into the particle time-offlight (PToF) region. NR-PM 1 particles are vaporized by a resistively heated surface at $\sim 600^{\circ} \mathrm{C}$ and undergo electron ionization $(70 \mathrm{eV})$. In this study, the HR-ToF-AMS was operated in the $\mathrm{V}$ mode at a $20 \mathrm{~s}$ time resolution during the determination of the NR-PM 1 composition, which included concentrations of OA, nitrate, sulfate, ammonium, and chloride. The HR-ToF-AMS ionization efficiency (IE) was calibrated using $350 \mathrm{~nm}$ ammonium nitrate particles with a number density of $\sim 300 \mathrm{~cm}^{-3}$. Default relative IE (RIE) values from the data analysis software were used for the other aerosol components (OA, sulfate, nitrate, ammonium, and chloride). Data were corrected for the composition-dependent collection efficiency (CDCE) in order to reduce uncertainty due to particle bounce on the surface of the vaporizer (Middlebrook et al., 2012). Concentrations measured in filter air blanks were used to determine minimum detection limits (MDLs) (Skoog et al., 1998). The MDLs $\left(\mu \mathrm{g} \mathrm{m}^{-3}\right)$ for the major chemical components (OA, nitrate, sulfate, ammonium, and chloride) were $0.18,0.03,0.02,0.04$, and 0.02 , respectively.

The HR-ToF-AMS data were analyzed using SeQUential Igor data RetRiEvaL (SQUIRREL, v1.57) and Peak Integration by Key Analysis (PIKA, v1.16) software (DeCarlo et al., 2006; Sueper and Collaborators, 2009) in Igor Pro (Wavemetrics Inc., v6.35). SQUIRREL and PIKA were used to determine the NR-PM 1 unit mass and high-resolution mass spectra, respectively, based on the NR-PM 1 chemical composition (OA, sulfate, nitrate, ammonium, and chloride) and ion fragment elemental composition (e.g., $\mathrm{C}_{x} \mathrm{H}_{y}, \mathrm{C}_{x} \mathrm{H}_{y} \mathrm{O}_{1}$, and $\mathrm{C}_{x} \mathrm{H}_{y} \mathrm{O}_{z}$ ). The operation of the UHSAS, an optical-scattering laser-based aerosol spectrometer that provides the number size distribution of particles between $0.06 \mu \mathrm{m}$ and $1 \mu \mathrm{m}$ with $1 \mathrm{~s}$ time resolution, has been described in detail elsewhere (Cai et al., 2008; Yokelson et al., 2011).

\section{Back-trajectory Analysis}

Several back-trajectory analyses were conducted for this study using the National Oceanic and Atmospheric
Administration (NOAA) Air Resources Laboratory (ARL) Hybrid Single-Particle Lagrangian Integrated Trajectory (HYSPLIT) model, which has been described in detail elsewhere (Draxler and Hess, 1997; Stein et al., 2015; Rolph et al., 2017). This was done in order to identify influxes of transported air pollutants during the research flight; HYSPLIT has been used in numerous and various previous studies to describe the long-range transport, diffusion, and deposition of atmospheric pollutants (Escudero et al., 2006; Lee et al., 2015; Stein et al., 2015; Lee et al., 2016). For the analysis of each case in this study, five HYSPLIT simulations with run times of $-72 \mathrm{~h}$ (from the data measurement time) were performed at $2 \mathrm{~h}$ intervals.

\section{RESULTS AND DISCUSSION}

\section{Overall Mean NR-PM Concentrations during the Campaign}

The overall mean NR-PM ${ }_{1}$ concentrations during the MAPS-Seoul campaign are shown in Table 2. The mean NR-PM ${ }_{1}$ concentrations vary from $13.0 \mu \mathrm{g} \mathrm{m}^{-3}$ (RF05) to $44.7 \mu \mathrm{g} \mathrm{m}^{-3}$ (RF06) during the seven research flights, throughout which OA accounted for $35-75 \%$ of the total NR-PM 1 concentrations. In this study, overall OM:OC, O:C, and $\mathrm{H}: \mathrm{C}$ values are 1.84-2.07, 0.54-0.71, and 1.28-1.41, respectively. Each research flight is described and compared to similar studies and locations in the following sections.

\section{Flight Type 1: 3D Spatial Distribution of Aerosol Chemical Composition in a Plume}

Fig. 2 shows temporal and spatial variations in the OA, sulfate, nitrate, and ammonium concentrations during RF02 near the west coast of Korea. RF02 was conducted near power plants and the Daesan Petrochemical Complex (DPC; $36.7^{\circ} \mathrm{N}, 126.2^{\circ} \mathrm{E}$ ), one of the largest emission sources in this region. In general, the NR-PM 1 plume moves west toward the sea after ascending from the DPC due to prevailing southeasterly winds. Near the DPC, NR-PM 1 concentrations were maximized at an altitude of $\sim 600 \mathrm{~m}$ and decreased above $600 \mathrm{~m}$. Farther to the NW in the plume, the mass concentrations of $\mathrm{OA}$ and nitrate increased with altitude up to $700 \mathrm{~m}$, and OA dominated the NR-PM 1 mass. During the descent at the end of the flight, however, sulfate was dominant closer to ground level beginning at 18:15, and the mass concentration of nitrate decreased.

Fig. 3 shows a Van Krevelen diagram of the RF02 data, which can be used to investigate the organic oxidation state 
Table 2. The overall mean NR-PM 1 concentrations and the elemental ratio of organics for each research flight during the MAPS-Seoul campaign.

\begin{tabular}{|c|c|c|c|c|c|c|c|c|}
\hline \multirow{2}{*}{$\begin{array}{l}\text { Research } \\
\text { flight \# }\end{array}$} & \multicolumn{5}{|c|}{ Mean concentration $\left(\mu \mathrm{g} \mathrm{m}^{-3}\right)$} & \multicolumn{3}{|c|}{ Mean ratio } \\
\hline & NR-PM 1 & $\mathrm{OA}$ & $\mathrm{NO}_{3}{ }^{-}$ & $\mathrm{SO}_{4}^{2-}$ & $\mathrm{NH}_{4}^{+}$ & $\overline{\mathrm{OM}} / \mathrm{OC}$ & $\mathrm{H} / \mathrm{C}$ & $\mathrm{O} / \mathrm{C}$ \\
\hline RF 01 & $15.17(6$. & 8. & 2.47 & $2.85(1$ & 1.73( & $1.86(0.13)$ & 0) & 0.54( \\
\hline RF 02 & $10.54(8.66)$ & 4.95 & 1.2 & 3.46 & 1.47 & 23 & 1.28 & 17) \\
\hline RF 03 & $22.48(13.75)$ & $9.14(5.55)$ & $2.11(2.33)$ & $8.07(4.08)$ & $3.16(1.82)$ & $1.96(0.09)$ & $1.32(0.07)$ & $0.62(0.06)$ \\
\hline RF 04 & $19.40(5.60)$ & $6.85(4.60)$ & & $7.67(2.53)$ & 2.93( & $1.97(0.19)$ & $1.39(0.12)$ & $0.62(0.14)$ \\
\hline & & 5.79 & & & & & & \\
\hline RF 06 & $44.71(29.92)$ & $33.39(27.40)$ & $3.24(2.48)$ & $5.27(2.63)$ & 2.80( & $1.84(0.05)$ & $1.37(0.04)$ & $0.53(0.04)$ \\
\hline RF 07 & $33.70(18.35)$ & $20.21(16.93)$ & $2.50(1.61)$ & $7.88(3.430$ & $3.14(1.06)$ & $1.90(0.06)$ & $1.35(0.06)$ & $0.57(0.05)$ \\
\hline
\end{tabular}

${ }^{a}$ The parenthesis indicates the standard deviation.
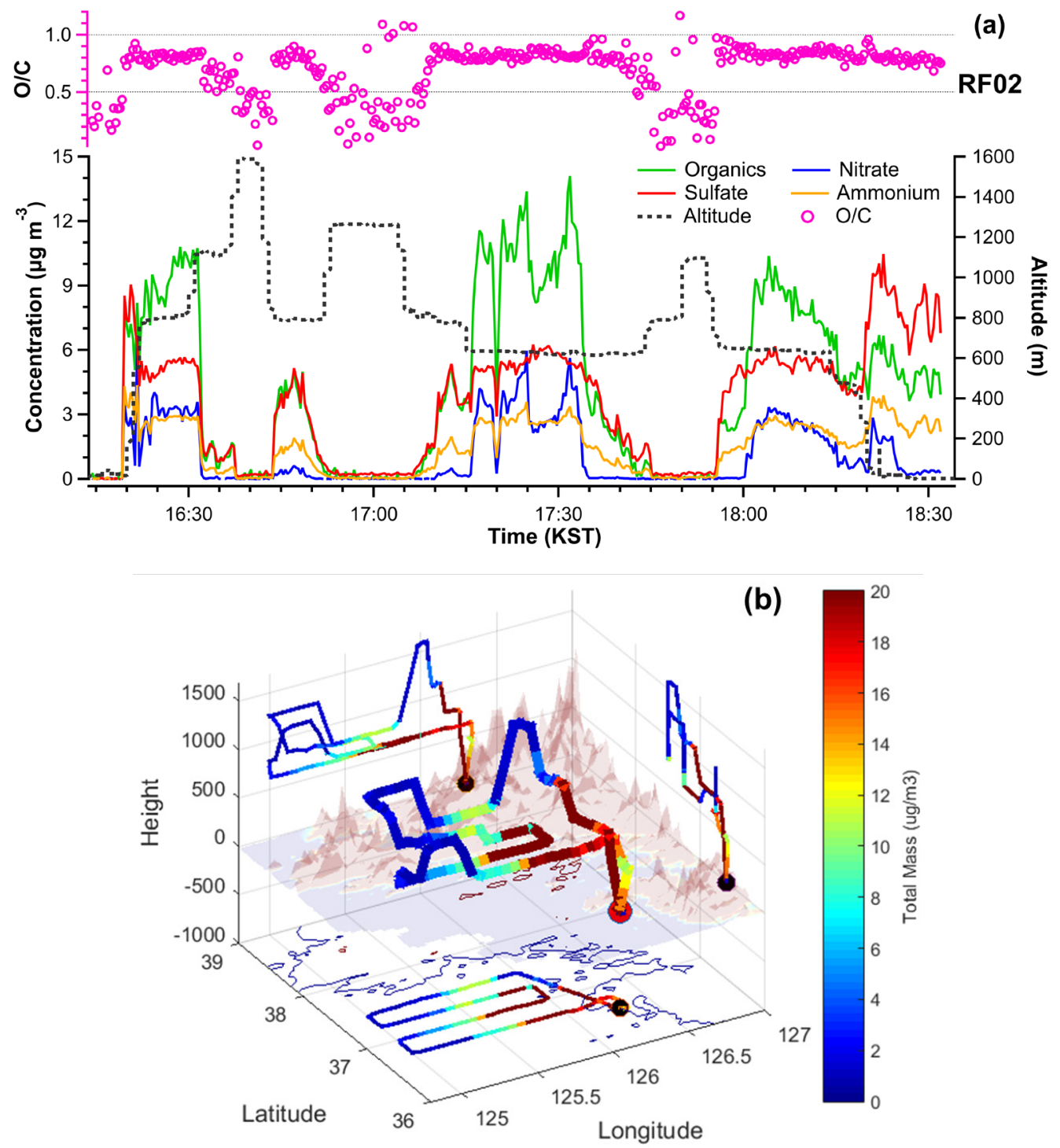

Fig. 2. (a) Timelines of NR-PM $M_{1}$ component concentrations and O:C; (b) spatial distribution of total NR-PM $\mathrm{N}_{1}$ (organics, nitrate, sulfate, and ammonium) during RF02 showing local topography in translucent red.

through changes in the $\mathrm{H}: \mathrm{C}$ and $\mathrm{O}: \mathrm{C}$ ratios. Generally, $\mathrm{H}: \mathrm{C}$ decreases and $\mathrm{O}: \mathrm{C}$ increases as $\mathrm{OA}$ emitted from a source is oxidized during long-range transport or in situ atmospheric chemical reactions (Chen et al., 2015). This continuous oxidation potentially increases $\mathrm{OA}$ mass concentrations and increases hydrophilicity, which may impact PM mass and climate (e.g., through changes in cloud behavior). Canagaratna et al. (2015) developed the Improved-Ambient (I-A) method 


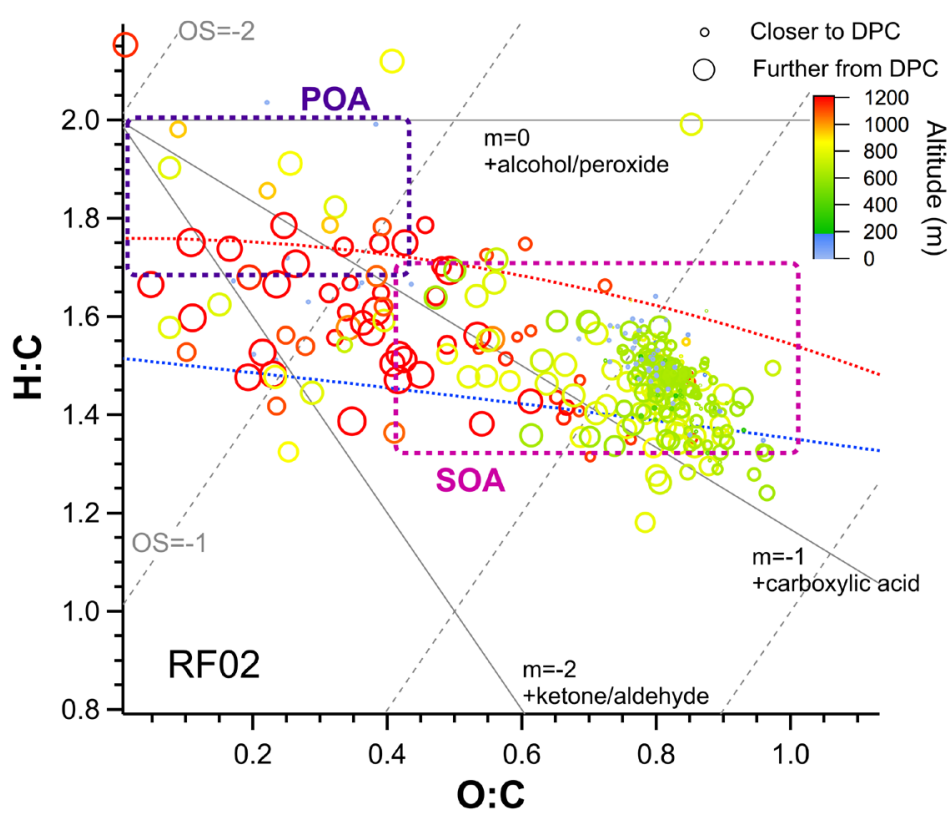

Fig. 3. Van Krevelen diagram showing RF02 data and broad ambient organic oxidation state ranges for secondary organic aerosol (SOA) and primary organic aerosol (POA) (Canagaratna et al., 2015); marker sizes indicate distance of the sampled point from the DPC and color indicates altitude, where green shades are generally within the high-concentration plume seen in Fig. 2(a).

to classify $\mathrm{O}: \mathrm{C}$, and $\mathrm{H}: \mathrm{C}$ values measured in previous field campaigns as primary or secondary aerosol (Fig. 3). According to the I-A method classification system for these RF data, the majority of the OA measured in RF02, and especially that in the plume (at altitudes of $\sim 0-800 \mathrm{~m}$, denoted by the blue to green markers in Fig. 3), is low-volatility oxygenated OA (LV-OOA). The OA is clearly less oxidized above the plume, at $>700 \mathrm{~m}$ (yellow to red markers in Fig. 3), likely indicating an air mass transition possibly delineated by the top of the boundary layer above the plume. Note that these higher-altitude data are also generally farther from the DPC (larger markers in Fig. 3), although there is no statistical relationship between distance from the DPC and oxidation indicators (including for data filtered to include only "inplume" data based on concentration; analysis not shown). Within the plume itself, the only notable change in $\mathrm{O}: \mathrm{C}$ occurs near the DPC during the final descent, where the O:C decreases slightly with decreasing altitude (Fig. 2(a)). Thus, the overall pattern appears to involve the rapid oxidation of emissions from the DPC to become a consistently oxidized plume overlain (at altitudes $>\sim 700 \mathrm{~m}$ ) by a less oxidized air mass.

\section{Flight Type 2: Vertical Profiles of Aerosol Chemical Composition and Physical Properties}

Both RF03 and RF06 investigated pollutant vertical profiles through spiral flights over the western coast of Korea. OA dominated the NR-PM 1 in both RF03 and RF06; the maximum OA concentrations in RF03 and RF06 were $23.5 \mu \mathrm{g} \mathrm{m}^{-3}$ and $98.8 \mu \mathrm{g} \mathrm{m}^{-3}$ at $870 \mathrm{~m}$ and $1720 \mathrm{~m}$, respectively. Like the maximum $\mathrm{PM}_{1}$ concentrations, maximum number concentration diameters (of $137.8 \mathrm{~nm}$ and $157.4 \mathrm{~nm}$ ) occurred at $870 \mathrm{~m}$ and $1720 \mathrm{~m}$ in RF03 and RF06, respectively (Fig. 4). The details of these two flights, the data for which indicate different dominant aerosol sources and processing, are discussed below.

In RF03, the number concentration gradually decreased with an increase in the flight altitude, and a decrease in the NR-PM $M_{1}$ concentration; this likely results from flying out of the most concentrated pollutant layer. Note that OA concentrations are lower than sulfate concentrations above $1000 \mathrm{~m}$, but higher below $1000 \mathrm{~m}$ (and that the relative concentrations of nitrate and ammonium also transition at $1000 \mathrm{~m}$ ). It suggests that the sources and/or processing of the particle populations differ above and below $1000 \mathrm{~m}$, which may approximate the planetary boundary layer height (PBLH), while the PBLH can vary widely (previous research has shown average summer values of $\sim 1000-1400 \mathrm{~m}$ over Seoul (Lee et al., 2013). It is likely that the particles above $1000 \mathrm{~m}$ altitude were derived from transport, which is generally associated with enhanced sulfate formation (see Fig. 4), and the particles below $1000 \mathrm{~m}$ altitude were derived from other sources. There were no significant changes in $\mathrm{O}: \mathrm{C}$, which fell in the LV-OOA range throughout the profile, with altitude.

The RF06 vertical profiles were almost the inverse of the RF03 profiles, showing sharp increases in number concentration, mean particle size, and NR-PM 1 species concentrations above $1250 \mathrm{~m}$. Near the surface, the sulfate concentration was higher than those of other species, which did not change significantly below $1250 \mathrm{~m}$. Above $1250 \mathrm{~m}$, all NR-PM $M_{1}$ species except for sulfate, and especially nitrate and OA, began to increase. The nitrate and OA concentrations had similar profiles and were both maximized at $1750 \mathrm{~m}$, suggesting that the nitrate sources and/or aging processes were similar to those of OA. O:C is lower (in the semi-volatile 

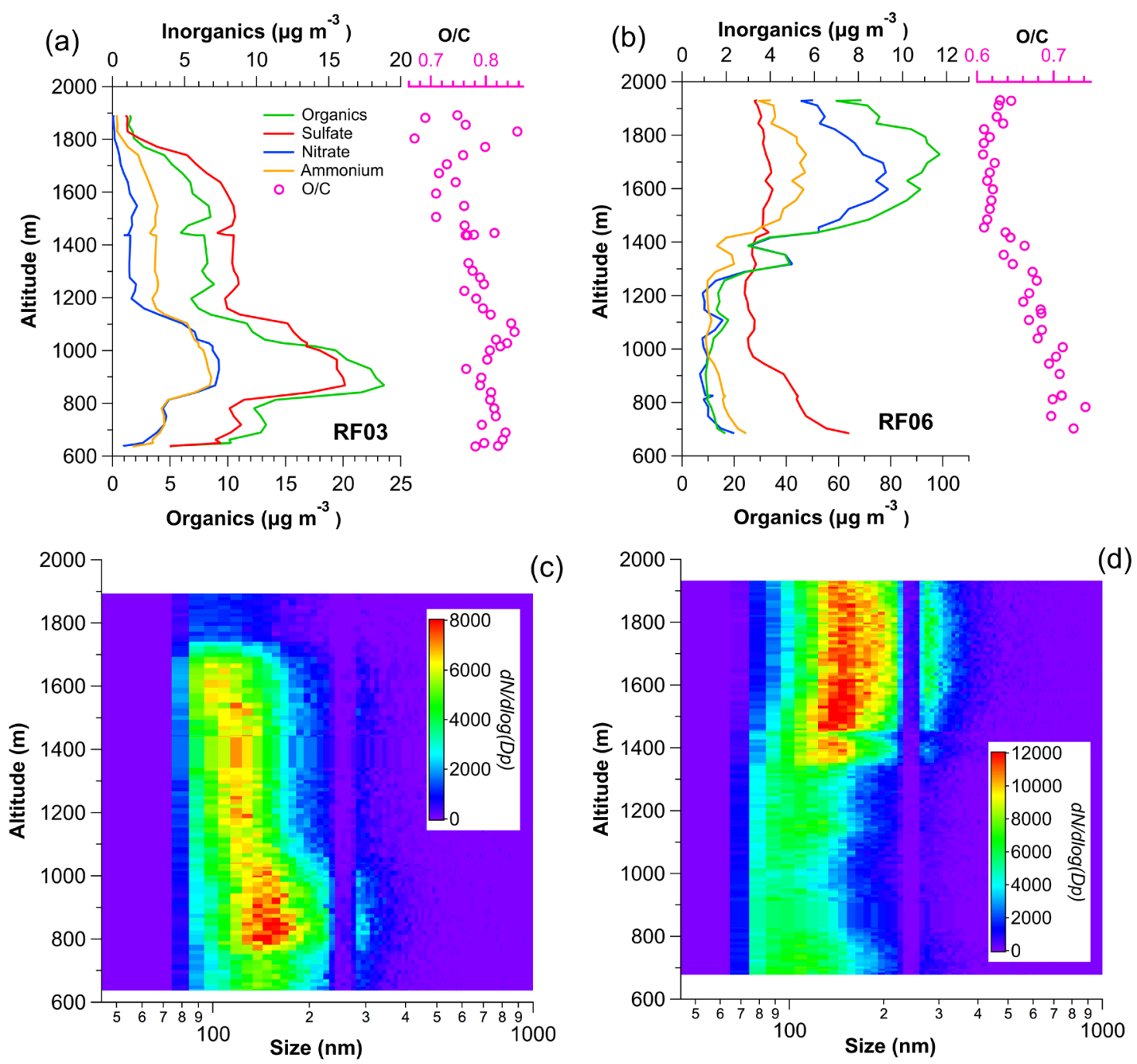

Fig. 4. Vertical profiles of NR-PM mass concentrations and O:C for (a) RF03 and (b) RF06 and particle size distributions for (c) RF03 and (d) RF06. The spiral flights were performed at $\sim 630-2000 \mathrm{~m}$.

oxygenated OA (SV-OOA) range) above $1400 \mathrm{~m}$ and increased with decreasing altitude below, moving well into the LV-OOA range near the surface. Thus, changes in size distribution, concentration, and degree of oxidation indicate that the particle population above $\sim 1300-1400$ m was more abundant, somewhat larger, less oxidized, and contained more organics and nitrate than that near the surface. The back-trajectory analysis was conducted for the spiral flight location $\left(36.594^{\circ} \mathrm{N}, 126.294^{\circ} \mathrm{E}\right)$ to identify any influxes of transported particles during RF06 (Fig. 5). HYSPLIT was run for 03:00 UTC on June 13, 2015, with a $-72 \mathrm{~h}$ run time and a starting height of $1800 \mathrm{~m}$ above sea level (ASL). The influx of external air pollutants carried by westerlies is confirmed at an altitude of $1800 \mathrm{~m}$ during the RF06; influxes of pollutants from foreign countries may negatively affect domestic air quality after mixing down to the surface, which has been evidenced in other studies. Kim et al. (2018) analyzed meteorological data and back trajectories during this campaign, suggesting that the RF06 had favorable conditions for a strong long-range transport (LRT) process over the whole Korean Peninsula.

\section{Flight Type 3: Aerosol Chemical Composition over the SMA and Surrounding Regions}

RF07 involved travel from Taean, through the SMA, to Wonju, back again to the SMA, and then to Taean (Fig. 6), covering the entire inflow and outflow region of the SMA and providing an ideal dataset for investigating SMA aerosol chemical properties. Outside the SMA, the mass concentrations of chemical species in NR-PM $\mathrm{P}_{1}$ were fairly similar in most areas, at $<20 \mu \mathrm{g} \mathrm{m}^{-3}$ (Fig. 7). OA was dominant in $\mathrm{NR}^{-\mathrm{PM}_{1}}$ in all regions, and sulfate was the second most abundant NR-PM 1 species over all regions except Seoul, where nitrate was the predominant inorganic species. West of the SMA, $\mathrm{O}: \mathrm{C}$ varies somewhat in the LV-OOA range but did not show clear trends. Over Seoul, where the aircraft rose sharply in altitude, OA increased in concentration and contributed $73 \%$ of the NR-PM $\mathrm{P}_{1}$ on average; the highest OA concentration was $120 \mu \mathrm{g} \mathrm{m}^{-3}$ at $2000 \mathrm{~m}$. O:C also increased during this flight segment, then increased again as the aircraft began to move downwind of Seoul (and decreased slightly, then held steady in altitude). This increase in oxidation downwind at constant altitude may reflect increasing photochemical 


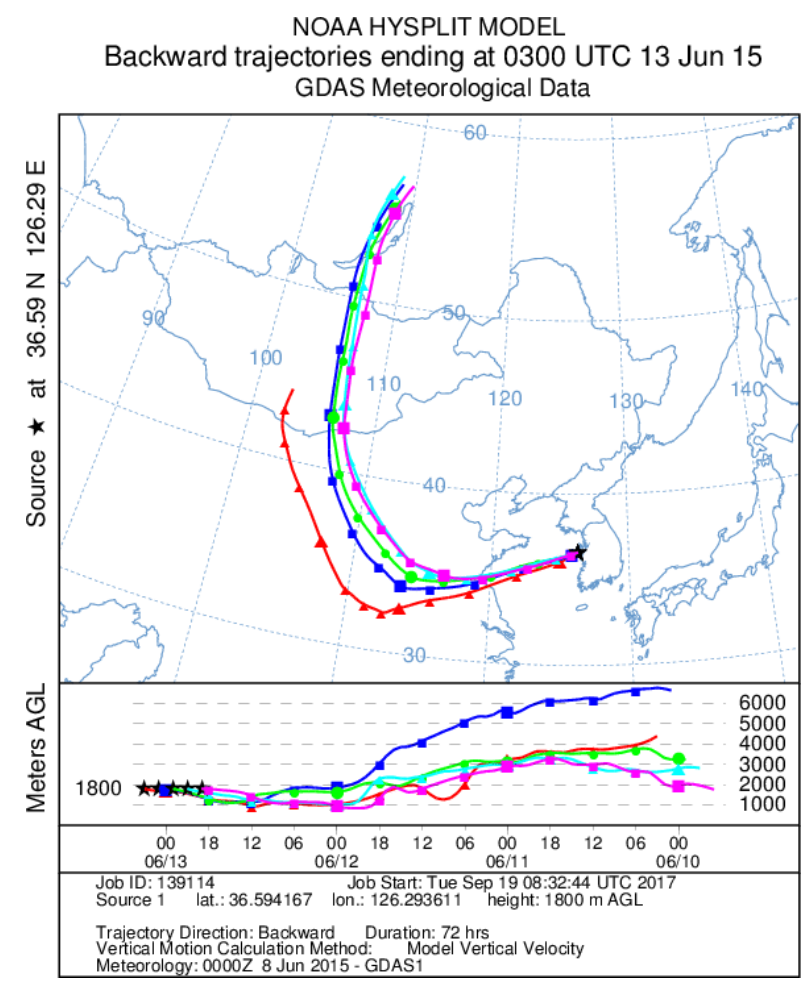

Fig. 5. Back-trajectory analysis for RF06.

oxidation of SMA emissions; however, due to the altitude of this flight segment $(\sim 1900 \mathrm{~m})$, and based on the profiles presented earlier, which often indicate disconnection between aerosol masses higher and lower in the atmosphere (likely separated by the boundary layer), we cannot state with certainty that this oxidation occurs in particles from the SMA. Indeed, during the return trip from downwind Wonju to Seoul at a constant altitude, the O:C increased slightly closer to Seoul, highlighting the differences in particle sources and/or processing with altitude. During RF07, the vast majority of the observed OA fell in the LV-OOA region (H:C: 1.32-1.68; O:C: $\sim 0.61-0.88$; Fig. S2).

(a)

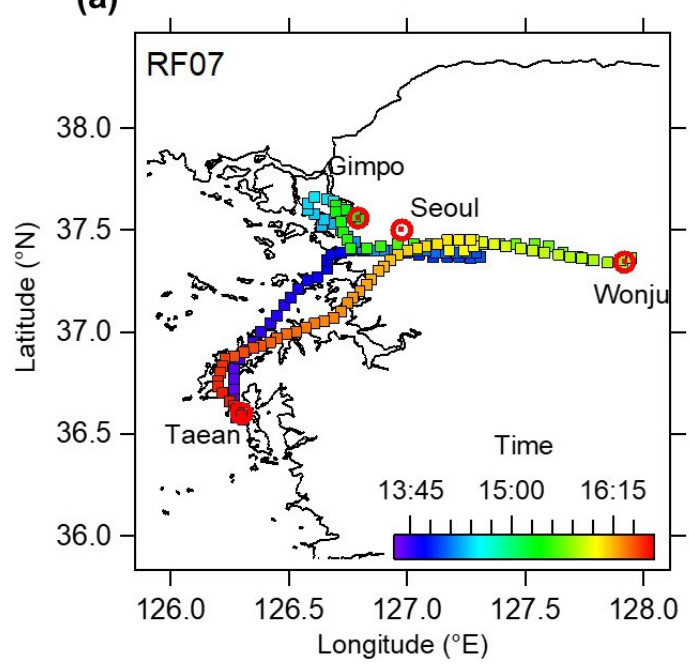

\section{CONCLUSIONS}

To investigate the horizontal and vertical spatial trends in aerosol physicochemical processing, seven RFs were conducted over the SMA from May till June 2015 during the MAPS-Seoul campaign. The NR-PM 1 composition and concentrations were examined using an HR-ToF-AMS, whereas the aerosol number distributions were measured as a function of size using a UHSAS. RF02 explored the spatial distribution of an NR-PM 1 pollution plume rising from the DPC, one of the largest emission sources in this region. In general, the prevailing southeasterly winds moved the plume westward, toward the sea. Near the DPC, the NR-PM concentrations peaked at an altitude of $\sim 600 \mathrm{~m}$. Farther to the northwest, however, the mass concentrations of the OA and nitrate in the plume continued increasing with altitude until $\sim 700 \mathrm{~m}$. Overall, OA dominated the composition, and the OA above $700 \mathrm{~m}$ clearly showed less oxidation, indicating the likely presence of an air mass transition zone (possibly delineated by the top of the boundary layer) over the plume; however, no statistical relationship between distance from the DPC and indicators of oxidation (including data filtered by concentration to include only "in-plume" data; analysis not shown) was found. Within the plume, the only notable change in the O:C occurred near the DPC during the final descent, where the O:C slightly decreased as the altitude dropped. RF03 and RF06 involved vertical spiral flights over the Taean and Anmyeon coasts. RF03 recorded OA concentrations that were higher than those for sulfate below $1000 \mathrm{~m}$ but lower than those above $1000 \mathrm{~m}$; no significant change in the $\mathrm{O}: \mathrm{C}$, which fell in the LV-OOA range for the entire profile, was detected. The differences in concentration and composition, especially in the dominant components, suggest that the particle origins and/or aerosol processes change above $\sim 1000 \mathrm{~m}$, where the enhanced sulfate formation identifies transport as the primary source, in contrast to the lower altitudes. RF06, on the other hand, measured sharp increases in the number concentration and mean diameter of the NR-PM 1 , less oxidized organic matter, and higher OA

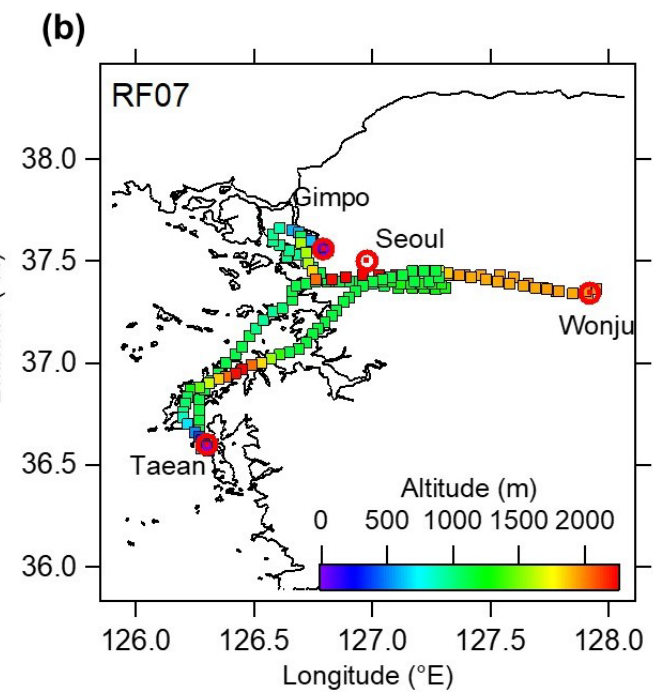

Fig. 6. Flight path during RF07 color-coded by (a) time (Korea Standard Time) and (b) altitude (m). 


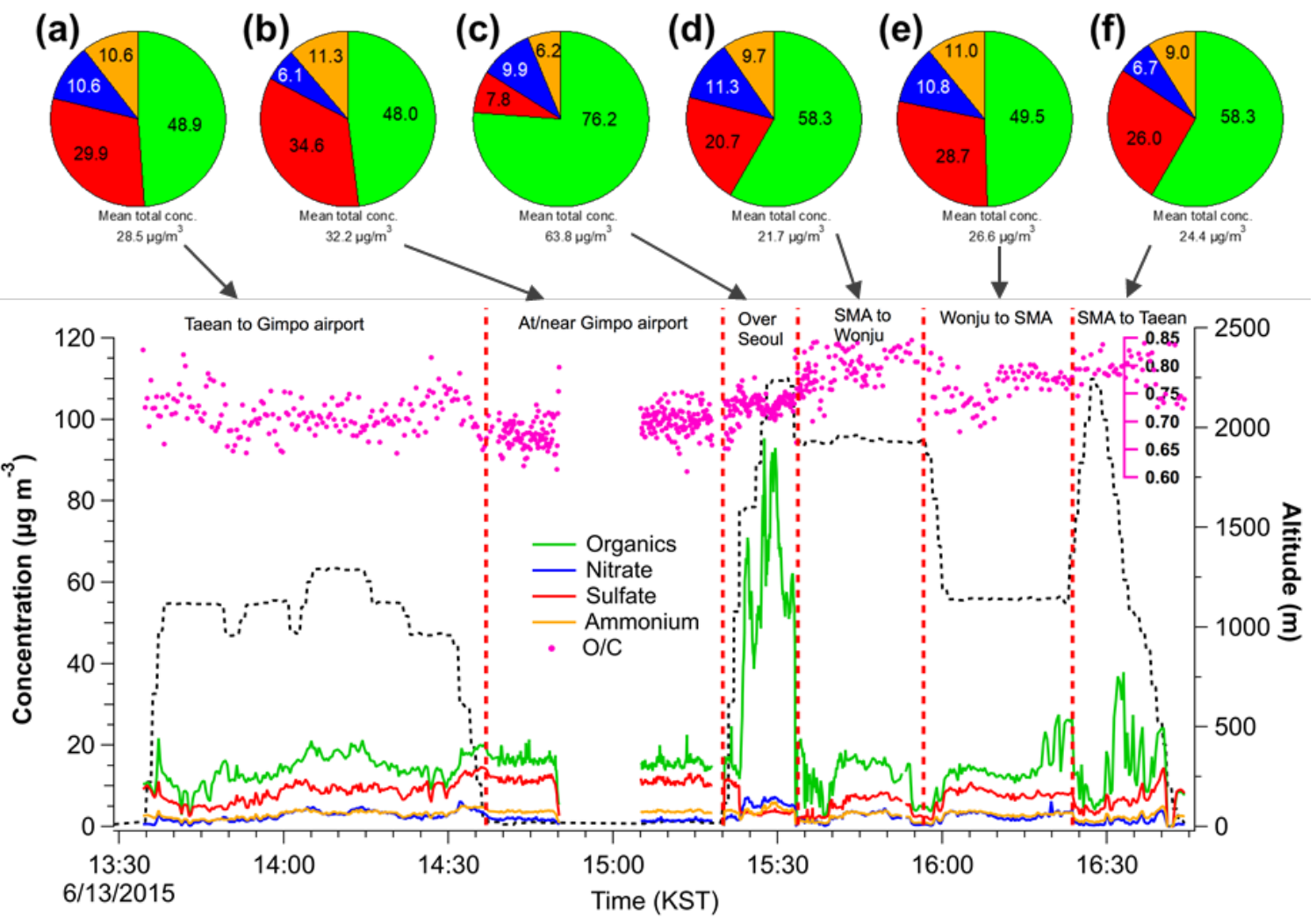

Fig. 7. Timelines of NR-PM 1 during RF07: (a) Taean to Gimpo airport, (b) aircraft inspection at Gimpo Airport, (c) passage through Seoul, (d) travel to Wonju, (e) journey from Wonju around the SMA, and (f) flight around the SMA back to Taean.

and nitrate concentrations above $1400 \mathrm{~m}$, indicating that the bulk of the particles were transported, which was confirmed by $-72 \mathrm{~h}$ HYSPLIT back trajectories. Decreased levels of particulate matter were observed at lower altitudes, although the sulfate concentration rose toward the surface. Finally, flights investigating the distributions of pollutants in the central, upwind, and downwind SMA regions generally detected high levels of oxidation downwind; however, as demonstrated by profiles obtained by previous flights, the aerosol masses differed between the low and high altitudes (probably inside and above the boundary layer, respectively).

Understandably, air quality is often viewed unidimensionally, from the ground, when focusing on its health effects. However, the complex vertical structure of particle sublayers, such as those identified in and around the Seoul Metropolitan Area, must be understood in order to better comprehend (and thus simulate) the climatic effects of aerosol, and the photochemical processing and sources of air pollutants in a variety of locations (e.g., urban, suburban, and remote sites).

\section{ACKNOWLEDGEMENTS}

This study was supported by the National Institute of Environmental Research (NIER-RP2019-152). Additional data processing was supported by the National Strategic Project-Fine Particle of the National Research Foundation of Korea (2017M3D8A1092015).

\section{SUPPLEMENTARY MATERIAL}

Supplementary data associated with this article can be found in the online version at http://www.aaqr.org.

\section{REFERENCES}

Aiken, A.C., Decarlo, P.F., Kroll, J.H., Worsnop, D.R., Huffman, J.A., Docherty, K.S., Ulbrich, I.M., Mohr, C., Kimmel, J.R. and Sueper, D. (2008). O:C and OM:OC ratios of primary, secondary, and ambient organic aerosols with high-resolution time-of-flight aerosol mass spectrometry. Environ. Sci. Technol. 42: 4478-4485. https://doi.org/10.1021/es703009q

Bae, M.S., Schauer, J.J., Lee, T., Jeong, J.H., Kim, Y.K., Ro, C.U., Song, S.K. and Shon, Z.H. (2017). Relationship between reactive oxygen species and water-soluble organic compounds: Time-resolved benzene carboxylic acids measurement in the coastal area during the KORUSAQ campaign. Environ. Pollut. 231: 1-12. https://doi.org/ 10.1016/j.envpol.2017.07.100

Bahreini, R., Jimenez, J.L., Wang, J., Flagan, R.C., Seinfeld, J.H., Jayne, J.T. and Worsnop, D.R. (2003). Aircraftbased aerosol size and composition measurements during ACE-Asia using an Aerodyne aerosol mass spectrometer. J. Geophys. Res. 108: 8645. https://doi.org/10.1029/2002 JD003226

Blechschmidt, A.M., Kristjansson, J.E., Ólafsson, H., Burkhart, J., Hodnebrog, Ø. and Rosenberg, P. (2012). 
Aircraft-based observations and high-resolution simulations of an Icelandic dust storm. Atmos. Chem. Phys. 12: 10649 10666. https://doi.org/10.5194/acp-12-10649-2012

Boris, A., Lee, T., Park, T., Choi, J., Seo, S. and Collett Jr, J. (2016). Fog composition at Baengnyeong Island in the eastern Yellow Sea: detecting markers of aqueous atmospheric oxidations. Atmos. Chem. Phys. 16: 437-453. https://doi.org/10.5194/acp-16-437-2016

Cai, Y., Montague, D.C., Mooiweer-Bryan, W. and Deshler, T. (2008). Performance characteristics of the ultra high sensitivity aerosol spectrometer for particles between 55 and $800 \mathrm{~nm}$ : Laboratory and field studies. J. Aerosol. Sci. 39: 759-769. https://doi.org/10.1016/j.jaerosci.2008.04.007

Canagaratna, M., Jayne, J., Jimenez, J., Allan, J., Alfarra, M., Zhang, Q., Onasch, T., Drewnick, F., Coe, H. and Middlebrook, A. (2007). Chemical and microphysical characterization of ambient aerosols with the aerodyne aerosol mass spectrometer. Mass Spectrom. Rev. 26: 185222. https://doi.org/10.1002/mas.20115

Canagaratna, M., Jimenez, J., Kroll, J., Chen, Q., Kessler, S., Massoli, P., Hildebrandt Ruiz, L., Fortner, E., Williams, L. and Wilson, K. (2015). Elemental ratio measurements of organic compounds using aerosol mass spectrometry: Characterization, improved calibration, and implications. Atmos. Chem. Phys. 15: 253-272. https://doi.org/10.5194/acp-15-253-2015

Cassiani, M., Stohl, A. and Eckhardt, S. (2013). The dispersion characteristics of air pollution from the world's megacities. Atmos. Chem. Phys. 13: 9975-9996. https://doi.org/10.5194/acp-13-9975-2013

Chen, Q., Heald, C.L., Jimenez, J.L., Canagaratna, M.R., Zhang, Q., He, L.Y., Huang, X.F., Campuzano-Jost, P., Palm, B.B. and Poulain, L. (2015). Elemental composition of organic aerosol: The gap between ambient and laboratory measurements. Geophys. Res. Lett. 42: 4182-4189. https://doi.org/10.1002/2015GL063693

Choi, N.R., Lee, S.P., Lee, J.Y., Jung, C.H. and Kim, Y.P. (2016). Speciation and source identification of organic compounds in $\mathrm{PM}_{10}$ over Seoul, South Korea. Chemosphere 144: 1589-1596. https://doi.org/10.1016/j. chemosphere.2015.10.041

DeCarlo, P.F., Kimmel, J.R., Trimborn, A., Northway, M.J., Jayne, J.T., Aiken, A.C., Gonin, M., Fuhrer, K., Horvath, T., Docherty, K.S., Worsnop, D.R. and Jimenez, J.L. (2006). Field-deployable, high-resolution, time-of-flight aerosol mass spectrometer. Anal. Chem. 78: 8281-8289. https://doi.org/10.1021/ac061249n

DeCarlo, P., Dunlea, E., Kimmel, J., Aiken, A., Sueper, D., Crounse, J., Wennberg, P., Emmons, L., Shinozuka, Y. and Clarke, A. (2008). Fast airborne aerosol size and chemistry measurements above Mexico City and Central Mexico during the MILAGRO campaign. Atmos. Chem. Phys. 8: 4027-4048. https://doi.org/10.5194/acp-8-40272008

Draxler, R.R. and Hess, G. (1997). Description of the HYSPLIT 4 modeling system. NOAA Technical Memorandum ERL ARL-230.

Drewnick, F., Hings, S.S., DeCarlo, P., Jayne, J.T., Gonin, M., Fuhrer, K., Weimer, S., Jimenez, J.L., Demerjian, K.L. and Borrmann, S. (2005). A new time-of-flight aerosol mass spectrometer (TOF-AMS)-instrument description and first field deployment. Aerosol Sci. Technol. 39: 637658. https://doi.org/10.1080/02786820500182040

Escudero, M., Stein, A., Draxler, R.R., Querol, X., Alastuey, A., Castillo, S. and Avila, A. (2006). Determination of the contribution of northern Africa dust source areas to $\mathrm{PM}_{10}$ concentrations over the central Iberian Peninsula using the Hybrid Single-Particle Lagrangian Integrated Trajectory model (HYSPLIT) mod. J. Geophys. Res. 111: D06210. https://doi.org/10.1029/2005JD006395el

Gurjar, B.R., Ravindra, K. and Nagpure, A.S. (2016). Air pollution trends over Indian megacities and their local-toglobal implications. Atmos. Environ. 142: 475-495. https://doi.org/10.1016/j.atmosenv.2016.06.030

Hecobian, A., Liu, Z., Hennigan, C.J., Huey, L.G., Jimenez, J.L., Cubison, M.J., Vay, S., Diskin, G.S., Sachse, G.W. and Wisthaler, A. (2011). Comparison of chemical characteristics of 495 biomass burning plumes intercepted by the NASA DC-8 aircraft during the ARCTAS/CARB2008 field campaign. Atmos. Chem. Phys. 11: 1332513337. https://doi.org/10.5194/acp-11-13325-2011

Hunton, D.E., Viggiano, A.A., Miller, T.M., Ballenthin, J.O., Reeves, J.M., Wilson, J.C., Lee, S.H., Anderson, B.E., Brune, W.H., Harder, H., Simpas, J.B. and Oskarsson, N. (2005). In-situ aircraft observations of the 2000 Mt. Hekla volcanic cloud: Composition and chemical evolution in the Arctic lower stratosphere. $J$. Volcanol. Geoth. Res. 145: 23-34. https://doi.org/10.1016/ j.jvolgeores.2005.01.005

Jayne, J.T., Leard, D.C., Zhang, X., Davidovits, P., Smith, K.A., Kolb, C.E. and Worsnop, D.R. (2000). Development of an aerosol mass spectrometer for size and composition analysis of submicron particles. Aerosol Sci. Technol. 33: 49-70. https://doi.org/10.1080/027868200410840

Jimenez, J.L., Jayne, J.T., Shi, Q., Kolb, C.E., Worsnop, D.R., Yourshaw, I., Seinfeld, J.H., Flagan, R.C., Zhang, X., Smith, K.A., Morris, J.W. and Davidovits, P. (2003). Ambient aerosol sampling using the Aerodyne Aerosol Mass Spectrometer. J. Geophys. Res. 108: 8425. https://doi.org/10.1029/2001JD001213

Kim, C.H., Lee, H.J., Kang, J.E., Jo, H.Y., Park, S.Y., Jo, Y.J., Lee, J.J., Yang, G.H., Park, T. and Lee, T. (2018). Meteorological overview and signatures of long-range transport processes during the MAPS-Seoul 2015 campaign. Aerosol Air Qual. Res. 18: 2173-2184. https://doi.org/10. 4209/aaqr.2017.10.0398

Kim, Y.P., Lee, G., Emmons, L., Park, R. and Lin, N.H. (2018). Preface to a special issue "Megacity Air Pollution Studies (MAPS)". Aerosol Air Qual. Res. 18: I-IV. https://doi.org/10.4209/aaqr.2018.09.maps

Korea, S. (2016). Population, households and housing unit. http://kosis.kr/statHtml/statHtml.do?orgId=101\&tblId=D T_1IN1602\&conn_path=I2\&language $=$ en.

Lee, G., Choi, H.S., Lee, T., Choi, J., Park, J.S. and Ahn, J.Y. (2012). Variations of regional background peroxyacetyl nitrate in marine boundary layer over Baengyeong Island, South Korea. Atmos. Environ. 61: 533-541. https://doi.org/ 10.1016/j.atmosenv.2012.07.075 
Lee, S., Kim, J., Choi, M., Hong, J., Lim, H., Eck, T.F., Holben, B.N., Ahn, J.Y, Kim, J. and Koo, J.H. (2019). Analysis of long-range transboundary transport (LRTT) effect on Korean aerosol pollution during the KORUSAQ campaign. Atmos. Environ. 204: 53-67. https://doi.org/ 10.1016/j.atmosenv.2019.02.020

Lee, S.J., Lee, J., Greybush, S.J., Kang, M. and Kim, J. (2013). Spatial and temporal variation in PBL height over the Korean peninsula in the KMA operational regional model. Adv. Meteorol. 2013: 381630. https://doi.org/10.1 155/2013/381630

Lee, T., Choi, J., Lee, G., Ahn, J., Park, J.S., Atwood, S.A., Schurman, M., Choi, Y., Chung, Y. and Collett Jr, J.L. (2015). Characterization of aerosol composition, concentrations, and sources at Baengnyeong Island, Korea using an aerosol mass spectrometer. Atmos. Environ. 120: 297-306. https://doi.org/10.1016/j.atmosenv.2015.08.038

Lee, Y.H., Choi, Y. and Ghim, Y.S. (2016). Classification of diurnal patterns of particulate inorganic ions downwind of metropolitan Seoul. Environ. Sci. Pollut. Res. Imt. 23: 8917-8928. https://doi.org/10.1007/s11356-016-6125-3

Middlebrook, A.M., Bahreini, R., Jimenez, J.L. and Canagaratna, M.R. (2012). Evaluation of compositiondependent collection efficiencies for the aerodyne aerosol mass spectrometer using field data. Aerosol Sci. Technol. 46: 258-271. https://doi.org/10.1080/02786826.2011.620 041

Oh, H.R., Ho, C.H., Kim, J., Chen, D., Lee, S., Choi, Y.S., Chang, L.S. and Song, C.K. (2015). Long-range transport of air pollutants originating in China: A possible major cause of multi-day high-PM $\mathrm{P}_{10}$ episodes during cold season in Seoul, Korea. Atmos. Environ. 109: 23-30. https://doi.org/10.1016/j.atmosenv.2015.03.005

Park, S.S., Jung, S.A., Gong, B.J., Cho, S.Y. and Lee, S.J. (2013). Characteristics of $\mathrm{PM}_{2.5}$ haze episodes revealed by highly time-resolved measurements at an air pollution monitoring supersite in Korea. Aerosol Air Qual. Res. 13: 957-976. https://doi.org/10.4209/aaqr.2012.07.0184

Rolph, G., Stein, A. and Stunder, B. (2017). Real-time environmental applications and display system: Ready. Environ. Modell. Software 95: 210-228. https://doi.org/ 10.1016/j.envsoft.2017.06.025

Skoog, D.A., Holler, F.J. and Nieman, T.A. (1997). Principles of instrumental analysis. Fifth Edition. Brooks
Cole Press. Pacific Grove, CA.

Stein, A.F., Draxler, R.R., Rolph, G.D., Stunder, B.J.B., Cohen, M.D. and Ngan, F. (2015). NOAA's HYSPLIT atmospheric transport and dispersion modeling system. Bull. Am. Meteorol. Soc. 96: 2059-2077. https://doi.org/ 10.1175/BAMS-D-14-00110.1

Sueper, D. and Collaborators (2009). ToF-AMS Data Analysis Software. http://cires1.colorado.edu/jimenezgroup/wiki/index.php/ToF-AMS_Analysis_Software

Sun, Y.L., Zhang, Q., Schwab, J.J., Demerjian, K.L., Chen, W.N., Bae, M.S., Hung, H.M., Hogrefe, O., Frank, B., Rattigan, O.V. and Lin, Y.C. (2011). Characterization of the sources and processes of organic and inorganic aerosols in New York city with a high-resolution time-offlight aerosol mass apectrometer. Atmos. Chem. Phys. 11: 1581-1602. https://doi.org/10.5194/acp-11-1581-2011

Wang, W., Ma, J., Hatakeyama, S., Liu, X., Chen, Y., Takami, A., Ren, L. and Geng, C. (2008). Aircraft measurements of vertical ultrafine particles profiles over Northern China coastal areas during dust storms in 2006. Atmos. Environ. 42: 5715-5720. https://doi.org/10.1016/ j.atmosenv.2008.03.042

Yokelson, R.J., Burling, I., Urbanski, S., Atlas, E., Adachi, K., Buseck, P., Wiedinmyer, C., Akagi, S., Toohey, D. and Wold, C. (2011). Trace gas and particle emissions from open biomass burning in Mexico. Atmos. Chem. Phys. 11: 6787-6808. https://doi.org/10.5194/acp-11-6787-2011

Zamora, L.M., Kahn, R., Cubison, M., Diskin, G., Jimenez, J., Kondo, Y., McFarquhar, G., Nenes, A., Thornhill, K. and Wisthaler, A. (2016). Aircraft-measured indirect cloud effects from biomass burning smoke in the arctic and subarctic. Atmos. Chem. Phys. 16: 715-738. https://doi.org/10.5194/acp-16-715-2016

Zhang, Q., Jimenez, J.L., Canagaratna, M.R., Ulbrich, I.M., Ng, N.L., Worsnop, D.R. and Sun, Y. (2011). Understanding atmospheric organic aerosols via factor analysis of aerosol mass spectrometry: A review. Anal. Bioanal. Chem. 401: 3045-3067. https://doi.org/10.1007/s00216-011-5355-y

Received for review, January 15, 2020

Revised, May 22, 2020

Accepted, May 25, 2020 